\title{
Sinking in Quicksand: The Demise of Victorian High Culture in America 1870-1915 Mitra Sharafi
}

ABSTRACT: Today, the cerm Victorinn implies snobbishness and rigidity. Our world, the result in part of a rebellion against Victorian formality and social hierarchy, celebrates the classless, the democratic, and the popular. It professes faith in the artistic judgment of all members of society regardless of ethnic origin, level of education or wealth. From the Victorian point of view, however, twentieth-century mass culture is accessible to all by appealing to the lowest common denominator; it is inclusive at the cost of a loss of education, refinement, and profundity. Turn-of-the-century America is the ideal subject for a study of the inceraction between Victorian high culture and modern mass culture; the period from 1870 to 1915 was one of drastic cultural metamorphosis. Social change threatened the foundations of high culture and eventually killed it, but not without the unintentional help of the Victorians' own self-alienating behaviour.

On the evening of 12 January 1905. Henry James dined two chairs over from President Theodore Roosevelt at the White House. One wonders if the atmosphere was rense; the President had privately referred to James as "that miserable little snob," while the writer thought Roosevelt was "a dangerous jingo" and "the mere monstrous embodiment of unprecedented and resounding Noise."2 More important, one wonders if either of the two men saw the irony of their situation. To the "Rough Rider" President, Henry James and his type were "effete," "over-civilised, over-refined, and over-sensitive." 1 To the expatriate man of letters, the President and his type must have represented the destroyers of nineteenth-century intellectualism, poise, and reserve. ${ }^{4}$ Henry James personified the old order: the refined, reserved, cultivated, and literary ideal of Victorian high culcure. Teddy Roosevelt, despite his blue-blooded roots, represenced the new: the more casual, fun-loving, rugged-living "man of action." In these two men two opposing ideals clashed: the 
aging ethos of Victorian high culcure and the reething ethic of modern mass culture.

The James-Roosevelt dinner at the White House caught America at a cultural curning point. For much of the nineteenth century, "middle class" America had aspired to embody the ideals of Victorian high culture. Between 1870 and 1915, however, high culture came to symbolise snobbishness, effeminacy, and puritanism. This discussion will examine the changing conditions behind this cultural transition with two aims in mind. First, it will seek to give a deeper understanding of the modern tendency to characterise formality and refinement as snobbish, ridiculous, and undesirable. In other words, it will see modern mass culture's preference for all that is casual, relaxed, and fun as a continuation of the turn-of-the-century revolt against Victorian ideals. Second, this discussion will underscore the way in which democracy, as an egalitarian outlook extending beyond the political context, has permeated the modern mentality to the extent that modern mass culture appeals to all by drawing upon the lowest common denominator, basic human instincts, rather than assuming certain levels of education or wealth.

Victorian high culture in America did nor die in its sleep, oblivious to its passing, but suffered a violent death between 1870 and 1915. The Victorians were convinced that they were being stifled by the materialism and cultural diversity of America. Undoubredly an emerging mass culture was inundating high culture, but defenders of high culcure, in seeking to defend Victorian standards, actually hastened elite culture's marginalisation by resorting to the rejection of the growing mass culcure. They insisted upon rigid canons of behaviour and taste, and, in so doing, prevented a synthesis of high and mass cultures. Metaphorically, Victorian high culture in America was sinking in quicksand; it tried to save itself by struggling violently, but the harder it struggled, the faster it sank.

Stow Persons is probably the first to have looked at this transition in any length. The Decline of American 
Gentility, first published in 1973, examines the response of the nineteenth-century gentry to the growth of democratic mass society, concluding that the latter exterminated the former. Persons attributes the frailty of high culture in our own day to the demise of genteel culture in the late Victorian period: "in the real world of cultural conflict the status of the high culture of which the gentry were always the patrons and practitioners has been found by many observers to be precarious in the extreme." ${ }^{\text {" The December }} 1975$ issue of the American Quarterly includes Daniel Walker Howe's "American Victorianism as a Culture," which is useful for its definition of Victorianism. Howe defines knowledge of the English language as a "communications system" which put its speakers in contact with the particular cultural heritage of "Anglo-Saxon" (American and British) law, literature, history, religion, and science. Familiarity with this heritage was a key prerequisite for members of the high cultural elite. Other characteristics of Victorianism included the insistence upon rationality, restraint, self-improvement, didacticism, and piety. John Kasson's Amusing the Million: Coney Island at the Turn of the Century (1978) approaches the demise of high culture through reactions to the thrilling roller coasters, the amusing freak shows, and the sexually permissive spirit of the New York amusement park, all symbols of everything that high culture discouraged and mass culture celebrated. Lewis Perry's Intellectual Life in America (1984) includes a chapter on "[t]he cultivated class in the late nineteenth century" which provides an interesting discussion on the development of the culcural consensus within the high cultural elite. Perry also examines the struggle between the sciences and humanities in university curricula as a symbol of the greater class tensions between the practical and material-minded nouveaux riches and the Victorian high cultural elite. Finally, Lawrence Levine's Highbrow/Lowbrow: The Emergence of Cultural Hierarchy in America (1988) provides a detailed account of the "sacralisation of culcure" in the late ninereenth century. Levine admits that culcural class definition grew increasingly rigid at the turn of the 
century, but leans toward the vision of a classless America before and after this transformation. He contends that audiences attending Shakespeare and Italian opera were, in the earlier nineteenth century, "simultaneously popular and elite." Levine is troubled by the distinction between "highbrow" and "lowbrow" artists and culture in the twentieth century. Nevertheless, his thesis concerning the Victorian gentry agrees with that of earlier historians in its identification of a well-defined and francic class of people trying to survive the drastic social, economic, and rechnological changes of the late nineteenth and early twentiech centuries.

This paper, while concurring with the general consensus within high culture historiography (that high culture sought to define itself toward the close of the last century and, in so doing, hastened its demise), seeks to contribute to the field by dissecting the social foundations of Victorian high culture. Specifically, it will isolate and trace the collapse of four conditions necessary to the survival of high culture at the turn of the century, namely a hierarchical or vertical view of culture, the prerequisites of education and wealth, the expectation (and desire) that culture stimulate the intellect and uplift the soul, and the necessity of an ethnically homogeneous population of Anglo-Saxon heritage.

A few preliminary remarks must preface this paper's main discussion, however, and a brief overview of these remarks can only clarify their role. Before all else, some fundamental terms will be explained, namely the use of Victorianism in the American context, nuances of the term culture, and a general description of Victorian culture and modern culture. Next, key premises will be addressed. First, for Victorian high culture to suffer demise requires that it enjoyed supremacy at one rime. Some would argue that high culture has always been popular only with a very small elite, and that in fact no cultural transition occurred at the turn of the century. This objection will be refured based upon the distinction between actual membership in a cultural group and the power of a cultural group to act as the ideal. Second, this paper interprets the relationship between Victorian high 
culcure and modern mass culture, as perceived by the Victorians, as a confrontation, not a synthesis. This interpretation presupposes that the advocates of Victorian high culture developed a degree of class consciousness. Interestingly, advocates of mass culture failed to define themselves as a cohesive group. This failure to develop cohesion seems to underscore the exclusivity and rigid selfdefinition of the Victorian class.

The term Victorianism seems odd to use in describing late nineteenth-century America, but, as Daniel Walker Howe notes, Britain acted as a cultural model for America in this period because "Americans worried lest their culture be insufficiently distinctive to sustain a proper national identiry." Virtually every age is accompanied by a quintessential place, a center of influence and ideals for the period. As Rome dominated Europe in A.D. 50, so London did the English-speaking world in the nineteenth century. The term Victorian America, then, implies Victorian Britain's influence on American cultural life. The popularicy of British figures like Matthew Arnold in America makes the term especially appropriate in the cultural sense.

The term culture also requires clarification. Victorian culture is the distinctive heritage of values, ideas, and techniques expressed in the religion, politics, and social life of Victorian America. ${ }^{8}$ High culture is best described as the literature, philosophy, art, music, drama, and cultivation fostered and sanctified by the elite class. Modern culture is the social mentality and values embraced by turn-of-thecentury Americans in rejection of Victorian culcure. Mass culture refers to the artistic tastes of modern culture. Interestingly, the broader meaning of culture as used in the terms Victorian culture and modern culture is of recent origin. The 1898 People's Webster Pronouncing Dictionary and Spelling Guide defined culture simply as "refinement."

The Victorian temperament can hardly be better captured than by a line of the song "America! America!" which was taught to school children in the 1890s: "Confirm thy soul in self control." 10 The ideal Victorian internalised 
a strong sense of duty and honour, and was hard-working, sober, disciplined, and pious. Victorians were obsessed with self-improvement and the improvement of others. Achieving mastery over one's "evil passions" in the name of selfimprovement meant sexual and emotional restraint. Through the cult of etiquette, individuals were taught to guard in the private realm an entire range of personal reactions and intimate activities like eating, coughing, scratching. Indeed, privacy, composure, and formality dictated proper behaviour. As one 1890 s etiquette guide recommended: "Never look behind you in the street, or behave in any way so as to attract attention. Do not talk or laugh loudly out of doors, or swing your arms as you walk. If you should happen to meet someone you know, take care not to utter their names loudly."1 Victorian restraint was rooted in the view that what was physical and natural in human beings was animalistic, embarrassing, and uncivilised. And while bodily functions and pleasures were deemed inappropriate and shameful, pleasures of the mind and soul were celebrated and cultivated by the Victorian mentality. Editor and author Charles Eliot Norton expressed the preeminence of spirituality when writing about the American poet James Russell Lowell in 1893: "[James Russell Lowell's] greatest service to [his students] was making them conscious ... of the preeminence of the things of the spirit over those of the flesh." 12

Modern culcure is best described as a repudiation of Victorian self-restraint and discipline. Albert Einstein's Theory of Relativity (1907) deposed the notion of absolute time and distance in science, and was extrapolated into the social context to crush the notion of absolutes of morality. Coupled with the weakening of religion, moral relativism resulted in a society which was less convinced of its moral duty to deny the natural in itself and in others. Materialism and emorional and sexual expressivity, an enjoyment of the temporal world, came to be the hallmark of modern culture.

Having defined key terms and phrases, let us examine basic premises. Some may argue that this paper's most basic 
assumption-that high culture was overtaken by mass culture at the turn of the rwentieth century-makes too much of the elite's sentimental yearnings for a nonexistant (and neverexisting) cultural "golden age." They might argue that mass culture and high culture did and do co-exist in all periods, and that the high cultural elite's scoffings are merely a pessimistic and self-indulgent false nostalgia. "What is the world coming to?" and "Things are not the way they used to be!" are the habitual condemnations of a segment of every population in every period. Allan Bloom would be one such "scoffer" in our own period:

There is no relation berween popular culture and high culture; the former is now all that is influential on our scene .... Classical music, once the only regularly recognisable class distinction between educated and uneducated, high and low, has been replaced by rock music. which contains nothing noble, sublime, profound, delicate, tasteful, or even decent, and has room only for the intense, changing, crude. and immediate, which Toqueville warned us would be the nature of democratic art. ${ }^{13}$

The Allan Blooms of turn-of-the-century America (Henry James, Charles Eliot Norton, and Catherine Fullerton Gerould, to name a few) were not merely bitter old men and women. Granted, popular culture (the world of dime novels, comic strips, band concerts, and circuses) did coexist in the Victorian period with the operas and art galleries of high culture just as popular culture co-exists with high culture today. Nevercheless, the birth and death of culcural ideals is of interest here, not the existence of high or popular culture. The middle class mimicked the cultural taste of the upper class for much of the nineteenth century. In the late twentieth century, this relationship has been inverted: it is now the middle class that acts as "arbiter of good taste"; the wealthy merely invest more money in a code of desires, 
styles, and pastimes dictated to them by, and hence held in common with, the majority of the population.

Thus, the desire to emulate the high cultural elite existed in the middle class in the Victorian period with an intensity that is absent roday. Lewis Perry claims that the middle classes were sometimes even more interested in refinement than was the privileged elite. The Chautauquan, a magazine manual for middle-class aspirants, was devoted "to the Promotion of True Culture," and strove to be "a high-class literary magazine adapted for the needs of practical people." ${ }^{14}$ Numerous women's clubs provided a link between literary and middle-class culture. This sense of respect and emulation even extended to the working class in some cases. Carroll D. Wright, the U.S. commissioner of labour statistics, wrote glowingly of the noble cultural longings of a factory woman who sat beside him on the train:

Her whole attention ... was engaged in studying a popular magazine, and it was impossible to refrain from watching her face and learning the subject which was attracting her; she was reading an article relative to some of the great works of our best artists, and studying the engravings which accompanied it. At the cost of a dime, she was bringing into her life, at the close of her day's labour, the company of the world's great artistic geniuses.

Wright was sure that in her home there must have been reproductions of art, "cheap and possibly common, but nevertheless a sure indication of the existence in her soul, of an aspiration after something higher than the drudgery she was compelled to follow."15 It was the overturning of the middle and working class' desire to emulate the high cultural elite, rather than the birth of a new culture, that took place in the period from 1870 to 1915.

If the advocates of Victorian high culture formed a defensive and belligerent class, they first had to achieve some degree of class consciousness. Cultural consensus was 
reached by the Victorian elire by the 1880 s. Lewis Perry refers to "the patrician castes who segregated themselves in resorts and country clubs from the 1880 s on." 16 The first country clubs were established in this period, among them the Meadowbrook Hunt Club in 1879, the Brookline Country Club in 1882, and the Country Club of Westchester in 1884. Neil Harris remarks upon the drift toward sharper cultural self-definition: "No other era witnessed the formation of so many clubs, societies, lodges and fraternal organisations. The Gilded Age was more properly a Guilded Age, an era of association for protection." 17 Scribner's, Harper's, Dial, and the Atlantic Monthly provided Victorians with literary fora through which to communicate with each other. A classical arts education from an Ivy League university served as a pedigree for high culture membership. John Kasson describes the Victorian advocates of high culture as a self-conscious elite of critics, ministers, educators, and reformers, drawn mainly from the Protestant middle class of the urban Northeast, who, in the wake of the disintegration of the old colonial gentry class, assumed cultural leadership, and embarked on a mission to refine and instruct an increasingly urban and industrial democracy. ${ }^{18}$

Cultural consensus among the advocates of mass culture, in marked contrast to those of high culture, never existed. An array of mutually antagonistic groups formed a loose anti-high culture front. Bread-and-butter union workers, "robber baron" industrialists, and Marxist intellectuals, were united in their anti-Victorianism, but on nothing else.

An 1898 edition of The Atlantic claimed that workers were being taught to regard "works of art and instruments of high culture, with all the possessions and surroundings of people of wealth and refinement, as causes and symbols of the labourers' poverty and degradation, and therefore as things to be hated." Late nineteenth-century America experienced a wave of demand for labour reform including two Pennsylvania mine lock-outs in 1873-4, the 1877 ribbon weavers' strike, and the 1893 Pullman strike. In 
1910, two-thirds of the workers in twenty-one major and manufacturing mining industries came from Eastern and Southern Europe or were native American blacks. ${ }^{19}$ As Anglo-Saxon homogeneity was a pre-requisite for Victorian high culture (a point which will be explained shortly), the high cultural elite felt threatened by the workers and excluded them from membership.

The so-called capicalist oppressors of the working classes and the materialistic enemies of the Victorians were the nouveaux riches or self-made millionaires: the Carnegies, Mellons, and Rockefellers of the Gilded Age. Persons notes that, beginning in the 1880 s, the older commercial families of the seaboard cities were thrust into the background by these new industrial, financial, and utilities magnates, many of them from cities of the interior, who did not share the cultural interests of the older mercantile elite. ${ }^{20}$ Thomas Wentworth Higginson declared that the glory of culture was its ethical distance from the shallow materialism of commerce and industry. ${ }^{21}$ Harvard philosopher George Santayana described the overpowering of the old elite by the new in 1911: "The truth is that one-half of the American mind, that not occupied intensely in practical affairs, has remained, I will not say high-and-dry, but slightly becalmed; it has floated gently in the backwater, while, alongside, in invencion and industry and social organisation the other half of the mind was leaping down a sort of Niagara rapids." 22

The nouveanx riches justified their new status using social Darwinistic arguments. To the high culture elite, industrialists asserted that they had achieved success through merit and not birth-right. To the labour reform movement, they argued that their power in society was won through the laws of survival of the fittest. As Richard Hofstadter notes, "[The industrialists] suggested that all attempts to reform social processes were efforts to remedy the irremediable, that they interfere with the wisdom of nature, that they could only lead to degeneration." 23 The Victorians despised the nouveaux riches because of the latter's cultural barbarity and 
materialism, and consequently excluded them from the ranks of the high cultural elite.

Certain turn-of-the-century intellectuals also contributed to the emergence of an "anti-elite" front. In the period just before World War I, Marxism gained the favour of young American intellectuals. Henry May described these new devotees of Marxist ideology, initiators of "a culcural revolution": "We can see the massive walls of nineteenth-century America still intact, and then turn our spotlight on many different kinds of people cheerfully laying dynamite in the hidden cracks. ${ }^{24}$ Marxism robbed the high cultural elite of potential members by attracting young Ivy Leaguers to its cause; it had no place in its ideal society for "arbiters of good taste." John P. Diggins asserts that "the young intellectuals cheerfully presided over the death of the 'genteel tradition' as they attacked its Victorian standards, polite manners and haute-bourgeois tastes, its Puritan heritage and decorous Brahmin literature, and, above all, its condescending certainty that it had found ultimate truth and absolute value."2s

The attack on Victorian high culture of a particular intellectual, Thorstein Veblen, is especially noteworthy. The maverick social scientist wrote his The Theory of the Leisure Class in 1899. In it, he denounced acquaintance with dead languages, philosophy, literature, and the concern with taste and ideals as trappings of "the regime of status." Culture, according to Veblen, was a system of wasteful ceremonies intended to preserve a sense of hierarchy. The "aberrant scions of the leisure class" were archaic impediments to the advancing science and industry of "the members of the industrious classes." 26

In marked contrast to the loosely-bound anti-elite coalition was the cohesive and embittered high cultural elite. High culture was contingent upon the four conditions al ready mentioned, that is, a hierarchical or vertical view of culture, the prerequisites of education and wealth, the expectation (and desire) that culture stimulate the intellect 
and uplift the soul, and the necessity of an ethnically homogeneous population of Anglo-Saxon heritage.

The modern attitude toward judging culcures is horizontal: we are taught that our evaluation of orher cultures ought to be relativistic. All cultures deserve equal attention; one culture is not more backward or civilised than another. On the contrary, the Victorians saw culture vertically or hierarchically, as a chain of progression running from the underdeveloped and inferior cultures of other ethnicities and the lower classes to the civilised and superior high culture of the Anglo-Saxon tradition. In a 1915 article on "The Extirpation of Culture," Catherine Fullerton Gerould commented on the anti-democratic nature of high culture:

Culture is not a democratic achievement, because culture is inherently snobbish. "Contact with the best that has been said and thought in the world" makes people intellectually exclusive, and makes them draw distinctions .... So long as democracy is simply a political matter, culture is left free to select its groups and proclaim its hierarchies. But once one extends the "I am as good as you are" formula beyond politics, culture, with its eternal distinction-making will die, for culturc induces a mighty scorn of those who do not know enough to be humble before the Masters .... We have all known for a long time that individual freedom and equality cannot coexist .... When even democracy has to reckon with the fact that its premises are all wrong, and that men are not born equal, - that hierarchies are inherent in human kind regardless of birth or opportunity,-it proceeds to do its utmost to equalise artificially. ${ }^{27}$

Advocates of high culture subscribed to a "trickledown" view of a cultured upper class. A society ought to spend its time and resources cultivating the privileged and talented few at the top, so that the rest of the population 
could be inspired to emulate this elite. The Boston music critic William F. Apthorp insisted upon this in his 1875 Atlantic Monthly music column:

Culture is infectious. Where the most highly cultivated nucleus exists, there will be the highest general cultivation. Nothing is more fatal to general culture than that intellectual and aesthetic communism which would have the foremost wait until those who lag behind shall have caught up with him .... To our thinking the man of high aesthetic nature and cultivation has an almost divine right to exercise and nourish his superior faculties in what transcendent manner he can. Let the mediocre majority feed after him, even on the crumbs that fall from his table, if need be. ${ }^{28}$

Democracy as a form of government and a set of legal and political values comprised only a small part of the high cultural usage of the word. The Victorians understood democracy to be an equaliser, both in a political and cultural sense, and the inversion of their "trickle-down" approach. An 1878 Atlantic Monthly writer gave voice to the Victorian fear of democratisation when he complained that equality and high quality were mutually exclusive:

A necessary tendency and peril of democracy, of a universal suffrage arrangement of society, is a general mediocrity, the adoption of low standards, a halting of the army of civilisation while we wait for the camp-followers to come up .... Their place is not in front, and the head of the column must move on. We must open the way ahead, and not merely fortify the rear of our position. ${ }^{29}$

The Victorians, however, were not bereft of sympathy or generosity for the masses. On the contrary, didacticism was a key ingredient of the Victorian high cultural oligarchy. 
What inspired Victorian didacticism was not only moral absolutism but also a faith in redemption. Ignorance and sin could be remedied given sufficient discipline and will. ${ }^{30}$ When Jane Addams and her genteel associates established Hull House for educated people to live in the urban slums of Chicago, she was not renouncing the values of her Victorian upbringing. Instead, she wanted to preserve "the blessings that we associate with a life of refinement and cultivation" by making them universal. ${ }^{31}$ Interest in uncultured Americans was aimed at transforming them into cultured Victorians, not at accepting them in their natural state, as would be the intent of mass culture. A reporter of the Chicago Dial complained in 1914 that "We are in danger of exalting the common man, and rejoicing in ... mediocrity." The only rightful control of culture was "centred in authority, - the authority of the trained judgment of the wisest and the best." 32

Two of the "wisest and best" cultural disciplinarians of the age were Frederick Law Olmsted, creator of Central Park in New York City, and Theodore Thomas, conductor of the New York Philharmonic. Olmsted had designed Central Park with the intention of providing a civilising and spiritually elevating environment for New Yorkers. He was soon irritared by the public's careless treatment of the park: "A large part of the people of New York are ignorant of a park .... They will need to be trained in the proper use of it, to be restrained in the abuse of it." ${ }^{33}$ Similarly, Thomas refused to tolerate uncivilised audience behaviour, and took an acrive role in imposing correct listener etiquette. Once he stopped the orchestra because the music interrupted conversation, and on another occasion, because a young man in the front row was noisily attempting to light his cigar ${ }^{34}$ In response to the complaint that his programs included too much Wagner and that the people did not like them, Thomas responded, "Then they must hear them [Wagnerian programs] till they do." Dial praised Thomas for eschewing "any attempt to win the applause of the multitude by concessions to vulgar prejudice or meretricious tastes," and 
asserted that the way to deal with the "average Philistine" was to say firmly: "This masterpiece deserved your attention ... for it has the power to raise you to a higher spiritual level. If you do not like it now, pray that you may learn to like it, for the defect is yours." 35

Hiram M. Stanley, a concerned Victorian reader, addressed a letter to Century Magazine in December 1892 which juxtaposed disgust for the commoner with the sincere wish to elevate the masses' moral condition through high culture:

Anyone who makes a study of the lower-class theatres and resorts in our large cities must be convinced of the need of more wholesome popular amusement .... In [these accessible resorts to freedom and relaxation] the chief elements are eating, drinking, smoking, society of the other sex, with dancing, music of a noisy and lively character, spectacular shows, and athletic exhibitions. In fact, we may define the "masses" as those whose sole delight is in these things .... In every city there is a large body of people whose enjoyment lies wholly in these lower channels, and for whom it is comparatively useless to open libraries, art-galleries, and museums ... [Stanley outlines a detailed plan for recreation centre of a moral nature for the "masses"] .... To be attractive, such an institution should come to them not in the guise of charity, or as a method of doing them good, but as an establishment soliciting their patronage. In fact, it should be kept a profound secret from the public that anything else than money-making is aimed at. ${ }^{36}$

Stanley's plan for a moral form of culture reflects the Victorian view that high culture encouraged social order, hence the "sweetness" (knowledge of the beautiful) and "light" (intellectual and moral enlightenment) which Matthew Arnold refers to in Culture and Anarchy. In 1870 


\section{Past Imperfect}

John Sullivan Dwight called music a "civilising agency," and an "influence that shall insensibly tone down our selfasserting and aggressive manners, round off the sharp, offensive angularity of character, subdue and harmonise the free and ceaseless conflicts of opinion." 37 Ten years later a founder of the Metropolitan Museum, Joseph Choate, expressed the belief that the diffusion of art "in its higher forms of beauty tends directly to humanize, to educate, and refine a practical and laborious people." ${ }^{38}$

The second tenet of high culture is that its enjoyment required a certain level of education and wealch. The assumption that one must be knowledgeable to gain pleasure from art seems at odds with the modern mentality. In the late twentieth century, one need not be culturally educared or refined to appreciate beauty. Conversely, the Victorians taught that high culture could not be appreciated without an education because they believed that human beings, in the natural state, were unenlightened and crude. In an 1892 public letter entitled "To Persons Desiring to Cultivate a Taste in Music," W.J. Henderson wrote that "a year of sincere study ought to lift the student far above the level of the commonplace, and enable him to stand where he will hear with the mind as well as the sense." 39 "People do not curn naturally to the best," asserted a writer in a 1903 edition of Collier's Weekly, "education is necessary to the appreciation of art." ${ }^{10}$ Education was costly in the nineteenth century, as was attending the opera or amassing a personal art collection. ${ }^{41}$ Only those with considerable wealth could properly appreciate high culture.

Third, Victorians expected fine music, art, and literature to be intellectually stimulating and spiritually fulfilling. They treated high culture with a religious reverence. The grave reactions of Theodore Thomas and Frederick Law Olmsted to bad public manners are cases in point. "Art for art's sake" was not a principle widely accepted among American Victorians; literature and the other arts were evaluated according to the elevation and instruction they offered their audience. 
Finally, high culture was based in the the Anglo-Saxon heritage and consequently favoured ethnic homogeneity. Being intrinsically related to education, Victorian high culture was rooted in the English tradition of literature, drama, art, and music. "Is there any single acquisition or faculty which is essential to culture," asked Charles W. Eliot, President of Harvard Universiry, in 1903, "except indeed a reasonably accurate and refined use of the mother tongue?" Knowledge of English put one in contact with the AngloSaxon tradition in religion, law, history, philosophy, morality and science.

The derivation of the terms "highbrow," first used in the 1880 s to describe intellectual and cultural superiority, and "lowbrow," first used shortly after 1900 to describe cultural inferiority, reflect the racial exclusivity of the Victorians. Both terms are taken from phrenology, the nineteenth-century pseudo-science of reading mental capacity and character from the shape of the skull. The more "primitive" the skull, the lower the brow; the closer to norchern and western Europe in ethnic origin, the higher the brow. In ascending order, the phrenological caregories ran: Low-browed ape, Human Idiot, Bushman, Uncultivared, Improved, Civilised, Enlightened, and finally at the top, Caucasian. Shakespeare, Milton, and Dickens were renowned for their high brows, and became emblematic of high culture and intelligence. ${ }^{43}$ The Victorian cultural hierarchy placed "Nordics" at the top, followed by recent immigrants from southern and eastern Europe, Mexican and Oriental migrants, and, at the very bottom, Afro-Americans and Africans.

A good indication of the Victorian tendency to equate ethnicity with primitivism is the Victorian view of music. Western symphonic music was seen to be the highest form of music, and "down in the basement, a kind of servants' hall of rhythm, we hear the hum of the Indian dance, the throb of the Oriental tambourines and kettledrums, the clatter of the clogs, the click of Slavic heels, the thumpty-tumpty of the Negro banjo, and, in fact, the native dances of the world. ${ }^{\text {"44 }}$ Accordingly, black music was deemed hedonistic, 


\section{Past Imperfect}

sensual, and unquestionably destructive to a moral order founded upon diligence and self-control. Rebelling against Victorian high culture, mass culture music (jazz, for example) would have deep and distinctively black roots to return to the natural and physical side of human beings.

The period from 1870 to 1915 witnessed rapid social change and economic and technological expansion on a scale which made Victorians fear for the survival of their delicatelytuned social hierarchy. In 1893. Charles Eliot Norton remembered an earlier era nostalgically: "There were no railroads, with their tremendous revolutionary forces; no great manufacturing cities; no flood of immigrants; no modern democracy. Old forms of life and old traditions prevailed." 45 "New wants were invented and simplicity of life went out of fashion," wrote an Atlantic Monthly journalist in 1878, "Into these conditions was plunged a population which had no sufficient moral safeguards whatsoever." 46 The revolution in communications and transportation gave birth to the telegraph, the telephone, and the automobile, giving increased freedom and mobility to a growing middle class. Producing printed matter was made easier and cheaper by the invention of steam-powered presses, and magazines and books were more efficiently distributed nationwide by trunkline railways connecring principal cities. When in 1913 Brander Matthews, professor of Dramatic Literature at Columbia University, wrote about the dangers of technology to the Victorian art of letter-writing, he unknowingly foreshadowed a much broader revolution in the public mindset which involved the replacement of formal elegance, discipline, and an economy of want with casual comfort, leisure time, and an economy of plenty:

"There are gains for all our losses," so the poet told us years ago; and our own experience tells us everyday that there are losses for our gains. The latest modern improvements, about which we are wont to be boastful, have all to be paid for. The invention of the relegraph and of the telephone, local and long-distance, could not 
fail to discourage letter-writing; and there are those who fear that our grandchildren will be able to publish no correspondence of this generation which will delight them with its leisurely charm as we are delighted by the easy grace of the epistolary communications of our grandparents. ${ }^{47}$

Modern culture launched a frontal assault upon the Victorians' hierarchical notion of culture, the first of high culture's four vital conditions. Catherine Fullerton Gerould attributed a significant portion of the extirpation of culture to "the increased hold of the democratic fallacy on the public mind." 48 The maxim vox populi vox dei (the voice of the people is the voice of God) embodies well the fundamental tenet of modern culture: people's inherent spontaneous wisdom, unguided by authority or by rradicion, is to be trusted. In the cultural realm, vox populi vox dei demanded democratic, classless art and music. The poet Walt Whitman insisted that culture could not be "restricted by conditions ineligible to the masses" and should not be created "for a single class alone, or for the parlours or lecture rooms." He placed his hopes for the creation of a classless, democratic culture in the leadership of the new "middling" groups. ${ }^{49}$ Mass culture was inclusive rather than exclusive, and horizontal rather than vertical.

The shifting of the cultural point of reference from the elite to the majority demanded the democratisation of higher education. The Victorians had relied on education as an indicator of class, and universal education blurred this social definition. Education was made increasingly available to all Americans regardless of class, and the wealth of the rapidly expandingeconomy offset the expense of establishing new educational institutions. ${ }^{\text {so }}$ The Second Morrill Act of 1890 , for example, provided annual federal appropriations to support land-grant colleges. Educational philanthropy also helped erase the class divisions that had previously prevented poorer Americans from being educated. In 1873 Johns Hopkins bequeathed $\$ 7$ million to found the Johns 


\section{Past Imperfect}

Hopkins University and Hospital in Balrimore. Hopkins had made his fortune as commission merchant, banker, shipowner, and banker. Andrew Carnegie, giant of the steel industry, founded numerous educational institutions and libraries in the first decade of the twentieth century. Leland Stanford founded Stanford University with the fortune he made in Western railroads. The University of Chicago was founded in 1891 by the oil profits of John D. Rockefeller. These institutions were founded largely by self-made men with little or no formal education. This in itself was a rejection of the Victorian ideal of a university fostering intellectual snobbery. ${ }^{51}$ The revolution in transportation and communications coupled with the mass productive capacity of American industry made art and music easily reproducible and accessible to the masses. One was no longer constrained by costly opera tickets as the cinema was readily accessible, even to the working classes.

If more Americans could educate themselves and new inventions made disseminating culture easier and cheaper, why did Victorian high culture wither instead of gaining popularity? The flooding of the educational system by mainstream America diluted Victorian educational values and standards. Increasingly, middle and working-class students entered the education system. Their English was colloquial or substandard, needless to say unrefined by Victorian standards. It was difficult and discouraging (for both teachers and students) to try to overcome such educationally impoverished social backgrounds and to attempt to achieve in reaching for Victorian standards of education. The democratic temptation was to relieve students of feelings of inferiority by suggesting that the language they spoke at home was not actually "incorrect" after all. The acceptance of "Black Language," for example, eliminated the need to learn Standard English. ${ }^{52}$ Because of the importance of a Victorian education to high culture, this dealt a devastating blow to Victorian high culture. Catherine Fullerton Gerould was disgusted by 
the impulse to put the college intellectually, as well as financially, within the reach of all. The colleges must not set up standards for themselves that the average boy or girl, from the ordinary school, cannot reach without difficulty, because that is undemocratic.... Learning, culture, were not meant to be adulterated so that any mental digestive process whatsoever could take them in .... The reverence for learning and culture has been largely replaced by a conviction that anything which has so great a reputation as a college degree must be put within the reach of all, even at the risk of making its repuration a farce. $^{33}$

The materialism of modern culture, moreover, changed attitudes towards education. One no longer became educated to be refined, culcured, and enlightened, but to obtain a high-paying job. There was also the growing suspicion that traditional, academicsubjects had no right to claim superiority over practical skills. "Almighty God was not mistaken," preached the educational reformer Jonathan Turner, "when he put the first man in the garden instead of the academy, and made his son a carpenter instead of a rabbi." Veblen argued that the humanities, as compared to the sciences, were elitist and irrelevant. ${ }^{55}$ Gerould was once again aghast:

No one whose consuming desire is either for food or for motor cars is going to care about culture, or even know what it is .... The real rest of a 'college education' is not the intrinsic value, but its success or failure in preparing the youth for something that has nothing to do with learning. Will it be of social or financial use to him? If not, why make sacrifices to get it? ... Americans suffer from ignorance of what real learning is and are consequently suspicious of it. Materialism and a consequent intellectual laxity have done destructive work in the colleges.... 
The attitude cowards Greek is an interesting sign of our democratic, materialistic times: there are two attitudes against teaching our children Greek: onc, that it is too hard; the other, that it is useless .... Culture has never renounced a thing because it was difficult, or because it did nor help people to make money. ${ }^{96}$

High culture and materialism could not coexist.

Mass culture's guarantee to amuse, thrill, and ritillate the masses overwhelmed the more delicate and loftier aims of Victorian high culture to uplift the spirit and purify the intellect. To appeal to the entire population, mass culture had to attract people from all social classes, with varying degrees of education and of diverse ethnic origins. Mass culture's allure could not depend upon an assumed level of education in the Anglo-Saxon tradition, as could the high culture of the Victorians. Instead, mass culture appealed to the physical, instinctual side of human nature, and was thus accessible to all Americans, regardless of ethnic origin, social class, or level of education. The "naughtiness" of Coney Island bathers and of Little Egypt's danse du ventre, the thrill of riding the Ferris Wheel, and the syncopated sensuality of jazz all typified the rejection of Victorian formality and composure. "We Americans want either to be thrilled or amused," declared George Tilyou, founder of Steeplechase Park (an amusement park), "and we are ready to pay well for either sensation." 7 Adherants of the new mass culture argued that true pleasure could not be dictated by cultural authorities, namely the Victorian elite, or by their education system. Mary Tucker Magill's short story "A Georgian at the Opera" recounted the experience of a rural Georgian who, having attended his first opera, warned others not to do the same "withour bein' prepared by readin' a library .... Maybe if I studied it when I was a new born infant, and kept at it stiddy [sic] till now, I might like the Grand Opery. As it is it is too much for me." 58 How could one truly enjoy a piece of art by being told that one should appreciate it? Vox populi vox dei voiced disregard for the views of the elite and put 
supreme faith in the unguided judgment of the average American. Mass culture rejected the reverence and discipline of high culture in favour of humour and self-indulgence.

Waves of European immigrants destroyed the ethnic homogeneity of Victorian America. ${ }^{59}$ Henry James resented the "hum of that babel of [immigrant] tongues" resulting from "the fruit of the foreign trees as shaken down there with a force that smothered everything else." ${ }^{60}$ An 1878 Atlantic Monthly journalist perceived immigrants to be "the most incongruous and unfavourable materials from all other countries," while Catherine Fullerton Gerould considered them to be "a racially and socially inferior population." ${ }^{\circ}$ She complained that the "public schools are so swamped by foreigners that all the teachers can manage to do is to teach the pupils a little workable English .... One has only to look at any official record of immigration, any chart of distribution of population by races, to see how the old American stock is being numerically submerged." 62

The Victorians' case of status anxiety seems natural in response to the disintegration of all conditions necessary to sustain high culture. "The Brahmins themselves are beginning to see that they are lost unless they compound with the materialists and make or marry money," wrote Carherine Fullerton Gerould, "-or increase, by aid of the materialists, what they have inherited." ${ }^{63}$ Even as early as 1857 , George Templeton Strong, a great chronicler of nineteenth-century America, complained that the streets of New York were "absolutely swarming, alive, and crawling with the unwashed Democracy .... The New Yorker belongs to a community worse governed by lower and baser blackguard scum than any city in Western Christendom, or in the world.... [W] submit to the rod and the sceptre of Maguires and O'Tooles and $O$ 'Shanes ... with corruption pervasive, especially in the rule of 'canaille' like railroad kings Fisk and Vanderbilt." The guardians of high culture dreaded the tastes of the growing middle class, the fortunes of industrial millionaires, and the ethnic heterogeneity of immigrants. 


\section{Past Imperfect}

The Victorians' response to a changing world was to retreat into their own private spaces whenever possible and to transform public spaces by rules, systems of taste, and canons of behaviour of their own choosing. ${ }^{65}$ Retreating into their own private spaces meant constructing divisions between themselves and the growing mass culture as a means of preserving their identity. In 1914, one Atlantic Monthly journalist hoped that, due to the growing popularity of the movie, "the art of the stage may escape from the proletariat, and again truly belong to those who in a larger sense are the "great ones of the earth." "Another magazine, The Nation, reminded its readers that movies were "not a very high art," that they revealed "the common predilection of the popular taste for the lurid and the fantastic," requiring "no thought and little attention." 67 The very fact of their accessibility to the masses made the following distasteful to the cultured: the blues, jazz, musical comedy, photography, comic strips, movies, radio, and popular comedians. In asserting their superiority by stressing the masses' inferiority, however, the Victorians made it virtually impossible for the general populace willingly to abide by Victorian codes of conducr and to want to be "saved" from their own aesthetic poverty and ignorance.

Advocates of Victorian high culcure could not resist the alienating and self-destructive urge to condemn mass culture. Henry James lamented that the Boston's Athenaeum, "this honoured haunt of all the most civilised-library, gallery, temple of culture," was now "put completely out of countenance by the mere masses of brute ugliness ... above the comparatively small refined facade .... It was heartbreaking." James complained that "the huge democratic broom" had swept away the old and ushered in an age of "the new, the simple, the cheap, the common, the immediate, and, all too often, the ugly ... in this heaped industrial battlefield." Indeed, James was "haunted" by a sense of dispossession. Constantly he was forced to tighten his "aesthetic waistband" to protect himself against "the consummate monotonous commonness ... in which relief, 
detachment, dignity, meaning, perished utterly and lost all rights. ${ }^{\text {} 68}$ Brooks Adams launched a lifelong campaign to "convince the economic rulers of America that they were stupid, shortsighted, and ignorant of their true interest," urging his fellow conservatives that they must save themselves by becoming conservative with a vengeance. ${ }^{69}$ Thomas Wentworth Higginson used high culture to criticise "a spirit of shallow commercialism in society at large. ${ }^{" 70}$ Charles Elior Norton abhorred mass sociery for its hedonistic absorption in the pursuit of happiness and the "full-blown commercial insolence" with which it flaunted its cultural likes and dislikes. ${ }^{\prime \prime}$ The progress of democracy saddened him by the "destruction of old shrines, the disregard of beauty, the decline of personal distinction, the falling off in manners." As friend of Carlyle and Ruskin, Norton saw art as both moral and aesthetic code. Most Americans, he believed, descended from "the oppressed, the servile, the peasantry, without intellectual traditions" who sought "material comfort in a brutal way. ${ }^{" 72}$ In 1888 Matthew Arnold claimed that the American "addiction to the funnyman" (a characteristic of mass culture) illustrated the lack of "the discipline of awe and respect" necessary to the creation of "distinction" in American culture. ${ }^{73}$ Certainly the urge to condemn and criticise in self-defence is understandable, but in this climate it succeeded merely in alienating Victorians from the majority of Americans.

While Mark Twain, Charlie Chaplin, and the Marx Brothers mocked the Victorian gentry with the satirical wit that Matthew Arnold hated, others launched the charge of effeminacy against the Victorian gentry. ${ }^{74}$ In 1877 Frederick Law Olmsted, creator of New York City's Central Park, was ridiculed as overly delicate and effete by The New York Evening Express when it referred to his "babble in the papers and the Society Circles about aesthetics and architecture, vistas and landscapes, the quiver of a leaf and the proper blendings of light and shade." 75 Mark Twain boasted that he had never tried to serve "dainties and delicacies" to the "thin top crust of humanity": "I have never tried in even one single 
instance, to help cultivate the cultivated classes." ${ }^{\prime 6}$ The poet Walt Whitman came to regard high Victorian culcure as insincere. In 1871, he wrote in Democratic Vistas that, with "the word Culture ... we find ourselves abruptly in close quarters with the enemy." 77 Military band conductor and composer John Philip Sousa contrasted modern to Victorian values when he said, "Notwithstanding the credo of musical snobs, 'popular' does not necessarily mean 'vulgar' or 'ephemeral.' Artistic snobbery is so ridiculous! Theodore Thomas gave Wagner, Liszt, and Tchaikovsky in the belief that he was educating his public. I gave Wagner, Liszt, and Tchaikovsky with the hope that I was entertaining my public." 78

Two events in the period from 1870 to 1915 capture the essence of the clash between mass and high culture. The first is the 1891 opening of New York City's Metropolitan Museum of Art to the public on Sunday afternoons, after prolonged prodding by political leaders. Twelve thousand eager visitors of a younger age and of working-class origins flooded the Met on opening day. Louis P. di Cesnola, the director of the Metropolitan, adopred a Victorian view of the occasion. He grumbled that the new visitors "brought with them peculiar habits which were repulsive and unclean," and "had come here fully expecting to see freaks and monstrosities similar to those found in [the Dime Museums on the Bowery to which they were accustomed]. Many visitors took the liberty of handling every object within reach; some went to the length of marring, scratching, and breaking articles unprotected by glass; a few proved to be pickpockets." Conversely, The New York Times bubbled: "Gleeful voices were heard through the corridors .... Boys tagged at their mothers heels and laughed at the queer-shaped pottery of the Egyptians. But they did no harm. A few could not help putting a hand on the piece of statuary now and then, but this is done just as much on a weekday, and cannor be spoken of as an evil exclusively attending Sunday opening. "79 The former attitude reflects the Victorian insistence on composure and restraint as well as a disgust for the lower classes, while 
the latter accepts a relaxing of Victorian formality, an acceptance of natural human expression in public places, and a democratic respect for the "commoner."

A second cultural snapshot is the 1893 World Columbian Exhibition in Chicago, "a mark of punctuation in American cultural history." ${ }^{80}$ Part of the world fair, the neoclassical White City, was constructed to inspire the public with feelings of nobility and civic duty. But it was the Midway Plaisance with its ferris wheel, Oriental theatres, Cairo Street with veiled Egyptian dancers, and villages from Ireland, Java, and Japan, that attracted most visitors. While Paderewski played Chopin in the White City, Scott Joplin plunked out ragtime in the amusement park. The President of the exposition's board of directors insisted that the White City was physically separated from the Midway to prevent "jarring contrasts" between "the beautiful buildings and grounds and the illimitable exhibits" of the former and the "amusing, distracting, ludicrous, and noisy attractions" of the latter. ${ }^{81}$ Nevertheless, the thrills and amusements of the Midway Plaisance drew larger crowds than did the spiritual rewards of the Victorian White City.

To make relevant the demise of Victorian high culcure to the contemporary cultural outlook, it is useful to examine the modern bias against high culture revealed in word choice. High culture pitted the cultured and the refined against the vulgar, mass culture compares the stuffy and the snobbish to the natural and the fin-loving. Another interesting use of language is the coupling and gradual replacement of the term art with entertainment. Cultural critic William A. Henry denounces this semantic shift:

the word "art" is rarely used at all. The preferred signifier is the word "entertainment," which correctly conveys that the aspirations are generally escapist, nostalgic or anodync. Entertainment promises to make you feel better, to help you forget your troubles, to liberatc you from having to think. Even when entertainment touches deep feelings, it does so as a gesture of reassurance, 
a combination of sentiment and sloganeering. This is what most people say they want, and the marker lets them have it, without anyone in a position of intellectual or social leadership telling them that they should ask more of themselves.... Where once Americans cheered for people who represented character traits they would like to embody and who had achieved greatness they would like to rival, we now cheer mainly for people who amuse us.... [The media's focus is on our] appetite for vulgarity and easy accessibility, and on the hype that substitutes for scholarship. ${ }^{82}$

The democratic outlook has infiltrated cultural judgments and preferences. "Popular culture," writes Henry, "is full of manifestations of the implicit, and sometimes explicit, idea that to be average is to be ideal .... The point is not to be right or knowledgeable, but simply to resemble the norm." ${ }^{83}$ To the democrat, mass culture is a great liberating force: an equaliser. To the high culture aesthete, it is more a qualitysacrificing leveller. Thus semantic dichotomies (refined) vulgar versus snooty/naturah art versus entertainment, and leveller versus equaliser) capture the essence of this discussion. The modern preference for the latter word in each contrast of terms is a legacy of the defeat of high culture in turn-ofthe-century America. 


\section{NOTES}

1 Theodore Roosevelt (in an 1894 letter to Brander Matthews), The Autobiography of Theodore Roosevelt (New York, 1958), 99

${ }^{2}$ Henry James in Edmund Morris, The Rise of Theodore Roosevelt (New York, 1979), 468

${ }^{3}$ Theodore Roosevelt in Lawrence W. Levine, Highbrow / Lowbrow: The Emergence of Cultural Hierarchy in America (Cambridge, Massachusetts, 1988), 236-237. Roosevelt hated the tone of James' stories: "His polished, pointless, uninteresting stories about the upper social classes of England make one blush to think that he was once an American." Autobiography of T. Roosevelt. 99. Of Henry Adams and Henry James, "that little emasculated man of inanity." Roosevelt commented that they were "charming men, but exceedingly undesirable companions for any man not of strong nature." Roosevelt in Morris, The Rise of Theodore Roosevelt, 416. Finally, commenting on Henry James' expatriotism, Roosevelt made the following vitriolic statement: "Thus it is for the undersized man of letters, who flees his country because he, with his delicate, effeminate sensitiveness. finds the conditions of life on this side of the water crude and raw; in other words, because he finds that he cannot play a man's part among men, and so goes where he will be sheltered from the winds that harden stouter souls." lbid., 468.

${ }^{4}$ On 16 January 1905, James wrote a letter to his close friend Edith Wharton in which he described his dinner with the President, Theodore Rex or Theodore I, as James called him: "[The President is,] verily, a wonderful little machine: destined to be overstrained perhaps, but not as yet, truly, betraying the least creak. It functions astoundingly, and is quite exciting to see. But it's really like something behind a great plate-glass 'on' Broadway." Leon Edel, ed. Henry James Letters, vol.iv (1895-1916), (Cambridge, Mass., 1984), 341. Richard Washburn Child observed that "You go to the White House, you shake hands with Roosevelt and hear him calk_and then you go home and wring the personality out of your clothes." Edmund Morris depicts the President as a daring, aggressive 'Natural Man': Roosevelt called critics of his Panama policy "a small bunch of shrill eunuchs" wh ile demonstrators against bloodsports were "logical vegetarians of the flabbiest Hindoo type." The 'wielder of the big stick' loved hunting and never tired of reminding the nation of his heroic 'cowboy and Indian' days in the war against Mexico. Child and Roosevelt in Morris, The Rise of Thoedore Roosevelt, 27 and 24. Roosevelt's aggressive physicality seems to betray the subtler and more literary temperament of James and his circle.

'Stow Persons, The Decline of the American Gentility (New York, 1973), vii

${ }^{6}$ Levine, Highbrow / Lowbrow, 85 
"Daniel Walker Howe, "American Victorianism as a Culture," American Quarterly, December 1975, 508

${ }^{8}$ Queen Victoria reigned in Britain from 1837 to 1901.

' Levine, Highbrow / Lowbrow. 224

${ }^{10}$ Levine. Highbrow / Lowbrow. 178

"Levine, Highbrow / Lowbrow, 198

"Charles Eliot Norton in Levine. Highbrow / Lowbrow, 199

"'Allan Bloom, The Closing of the American Mind (New York, 1987). 322; 68-81

14 The Chautauquan in Lewis Perry, Intellectual Life in America: $A$ History (New York, 1984), 273. The Chautauquan was unpopular with followers of modern culture. The magazine was the organ of the Chautauquan Institution, which offered adult education classes. Publishing began in 1880, and The Chautauquan's decline resulted in its merger with the Independent in 1914.

${ }^{15}$ Carroll D. Wright in Perry, Intellectual Life in America, 270-271 n 1" Perry, Intellectual Life in America, 269

${ }^{17}$ Neil Harris, ed. The Land of Contrasts 1880-1901 (New York, 1970), 17

${ }^{18}$ John F. Kasson, Amusing the Million: Coney island at the Turn of the Century (New York, 1978), 4

19 Herbert G. Gutman, Work, Culture, and Society in Industrinlising America: Essays in American Working-Class and Social History (New York, 1977), 22

${ }^{20}$ Persons, Decline of the American Gentility, 277

${ }^{21}$ T.W. Higginson in Persons, Intellectual l. ife in America, 278

22 G. Santayana in Persons, Intellectual Liff, 279

2" Richard Hofstadter, Social Darwinism in American Thought (New York, 1944), 7

${ }^{24}$ Henry May in Stanley Coben, "The Assault on Victorianism in the Twentieth Century," American Quarterly. December 1975.605

"John P. Diggins. The American Leff in the Twentieth Century (New York, 1973), 77

${ }^{26}$ Thorstein Veblen in Perry, Intellectual Life in America, 277-8

2" Katherine Fullerton Gerould, "The Extirpation of Culture," The Atlantic Monthly Magazine, October 1915, 446-447

${ }^{28}$ William F. Apthorp, "Music," The Atlantic Monthly Magazine, January 1875, 122-124

29 "Certain Dangerous Tendencies in American Life," The Atlantic. October 1878, 399

"naniel Walker Howe, "American Victorianism as a Culture," American Quarterly, December 1975, 527

"Jane Addams in Perry, Intellectual Life in America, 270)

"2 "High-Brow," Dial, April 1, 1914, 287-288

"Olmsted in Levine, Highbrow / Lowbrow. 183 
4 "Editor's Easy Chair," Harper's, April 1886, 80

"Theodore Thomas and Dial in Levine, Highbrow / Lowbrow. 189

${ }^{4}$ Ietter by Hiram M. Stanley, Century Magazine, December 1892, 476 "John Sullivan Dwight. "Music as a Means of Culcure," The Atlantic, September 1870,326

soseph Choate in Levine, Highbrow / Lowbrow, 201

39 W.J.Henderson. "To Persons Desiring to Culcivate a Taste in Music," Century Magazine, December 1892, 312-314

to Collier's Weekly, December 26, 1903, 22-23, in Levine, Highbrow I Lowbrow, 211

"One gets a good sense of the cost of education by skimming through the classified sections of magazines of the period. The May 1913 issue of Munsey's Magazine, for instance, includes ads for Penn Hall, a preparatory school for girls charging $\$ 425$ per year; the Peddie Institute, a similar school for boys charging $\$ 400$ to $\$ 500$ per year; and the Marsha Washington Seminary, a post-secondary women's college charging $\$ 600$ to $\$ 800$ per year. In the same issue, Rochester postal workers are offered roughly $\$ 1000$ per year; female nurses, $\$ 500$ to $\$ 1000$ per year; and professional photographers and salesmen. $\$ 1000$ to $\$ 2000$ per year. Sending several children to preparatory school on such incomes seems unlikely. Munsey's Magazine, May 1913, 11-20. 12 Charles W. Eliot, "A New Definition of the Cultivated Man," The World's Work, August 1903, 3811

4" Levine, Highbrow / Lowbrow, 222

"New Orleans Times-Picayune, June 20, 1918, in Levine, Highbrow / Lowbrow. 221

"Charles Eliot Norton, "James Russell Lowell," Harper's, May 1893. 848

46 "Certain Dangerous Tendencies in American Life," The Atlantic, October 1878, 388

"Brander Matthews. "Modern Essays," Munsey's Magazine, May, 1913, 268

${ }^{18}$ Catherine Fullerton Gerould. "The Extirpation of Culture," The Atlantic, October 1915,446

19 Walt Whitman in Levine, Highbrow / Lowbrow. 225

${ }^{40} \mathrm{It}$ is interesting to note that wealth was concentrated in the hands of industrial millionaires, although it appeared to distribute itself generously within the growing middle class.

"Danicl J. Boorstin. The Americans: The Democratic Experience (New York, 1973), 489

'Ilbid., 455

"Catherine Fullerton Gerould, "The Extirpation of Culture," The Atlantic, October, 1915, 449

"Jonathan Turner in Boorstin, The Americans, 487

ss Perry, Intellectual Life in America, 278 
"Catherine Fullerton Gerould. "The Extirpation of Culture," The Atlantic, October, 1915, 450

"George C. Tilyou in John Kasson, Amusing the Millions (New York: Hill and Wang, 1978), 58

ss Mary Tucker Magill, "A Georgian at the Opera," Harper's, June $1835,135-139$

"The late nineteenth century saw 18 million Europeans immigrate to the United States. This wave of immigrants was primarily from Southern and Eastern Europe. Italians, Jews, and Poles were the greatest in number, followed by Hungarians, Greeks, Turks, and Armenians. Four of every five of these immigrants settled in the northeastern United States (centre of American Victorianism) or in Mid-Western industrial towns. The years $1845-1854$ marked another flood of immigrants, of which 85 percent had been Irish fleeing the Irish Potato Famine and 12 percent German following the wave of liberal revolutions led by German workers.

"n Henry James in Levine. Highbrow / Loubrow, 207

(1) "Certain Dangerous Tendencies in American Life," The Atlantic, October 1878, 385-402, and Catherine Fullerton Gerould, "The Extirpation of Culture," The Atlantic. October 1915. 446

62 Cacherine Fullerton Gerould, "The Excirpation of Culture," The Atlantic, October 1915, 451

6: lhid., 452

${ }^{\leftrightarrow}$ George Templeton Strong in Levine, Highbrow/Lowbrow, 174-175

"Levine. Highbrous / Lowbrow. 177

"Annie Nathan Meyer, "The Vanishing Actor: And After," The Atlantic. January 1914, 96

"The Nation in Levine, Highbrow / Lowbrow, 232

${ }^{68}$ Henry James in Levine, Highbrow / Lowbrnu, 173

${ }^{69}$ Perry Miller, ed. American Thought Civil War to World War I (New York, 1954), xii

${ }^{70}$ Perry, Intellectual Life, 277

"C.1:. Norton in Persons, Decline, 298

"C.E. Norton in Howard Mumford Jones, The Age of Energy: Varieties of American Experience 1865-1915 (New York, 1970), 238-9

"Matthew Arnold in Levine, Highbrow / Lowbrow. 212

${ }^{74}$ Mark Twain is remembered for ridiculing the safety precautions taken by the Metropolitan Museum of Art directors to control the unruly working class crowds of Sunday visitors. When requested to leave his cane in the cloakroom. Mark Twain exclaimed: "Leave my cane! Leave my cane! Then how do you expect me to poke holes through the oil paintings?" Mark Twain in Levine, Highbrow / Lowbrow. 185.

"The New York Evening Express, 1877 in Levine, Highbrow/Lowbrow, 239

". Mark Twain in Perry, Intellectual Life in America. 274 
- Wale Whitman in Perry, Intellectual Life in America, 274

78 John Philip Sousa in Levine. Highbrow / Lowbrow. 237

$\rightarrow$ Louis P. di Cesnola and The New York Times in Levine, Highbrow /Lowbrow, 183

so Henry Nash Smith, ed. Popular Culture and Industrialism 1865 1890 (New York, 1967), xv

"Levine, Highbrow / Lowbrow, 210

${ }^{82}$ Robert H. Wiebe, The Search for Order $1877-1920$ (New York: Hill and Wang, 1967), 156

3. William A. Henry, "The peasants celebrate themselves," The Globe and Maih 13 August, 1994, D5

*t Henry, The Globe and Maih DS 